\title{
ANALYSIS OF RISK FACTORS FOR DEVELOPMENT OF COGNITIVE DISORDERS IN MAINTENANCE HEMODIALYSIS PATIENTS - PILOT STUDY
}

Milena Jovanovic ${ }^{1}$, Zeljko Todorovic ${ }^{2}$, Dragan Milovanovic ${ }^{2,3}$, Branislava Draskovic ${ }^{1}$, Andreja Todorovic ${ }^{4}$, Dejan Petrovic ${ }^{1,2}$ ${ }^{1}$ Clinic for Urology, Nephrology and Dialysis, Center for Nephrology and Dialysis, Clinical center "Kragujevac", Kragujevac, Serbia ${ }^{2}$ Faculty of medical sciences Kragujevac, University of Kragujevac, Kragujevac, Serbia ${ }^{3}$ Service of clinical pharmacology, Clinical center “Kragujevac”, Kragujevac, Serbia ${ }^{4}$ Department of Cardiology, General Hospital of Cuprija, Cuprija, Serbia

\author{
ANALIZA FAKTORA RIZIKA ZA RAZVOJ KOGNITIVNIH \\ POREMEĆAJA KOD BOLESNIKA NA HEMODIJALIZI - PILOT STUDIJA \\ Milena Jovanović ${ }^{1}$, Željko Todorović ${ }^{2}$, Dragan Milovanović ${ }^{2,3}$, Branislava Drašković ${ }^{1}$, Andreja Todorović ${ }^{4}$, Dejan Petrović ${ }^{1,2}$ \\ ${ }^{1}$ Klinika za urologiju, nefrologiju i dijalizu, Centar za nefrologiju i dijalizu, Klinički centar "Kragujevac”, Kragujevac, Srbija \\ ${ }^{2}$ Fakultet medicinskih nauka Kragujevac, Univerzitet u Kragujevcu, Kragujevac, Srbija \\ 3Služba za kliničku farmakologiju, Klinički centar "Kragujevac", Kragujevac, Srbija
}

Received / Primljen: 09. 07. 2016. ${ }^{4}$ Odeljenje kardiologije, Opšta bolnica Ćuprija, Ćuprija, Srbija

Accepted / Prihvaćen: 14. 10. 2016.

\begin{abstract}
Prevalence of cognitive disorders is high in maintenance hemodialysis patients. Montreal cognitive assessment (MoCA) is used for detecting and evaluation of cognitive disorder degree in this patient population. In examined patient population, only $5(12.5 \%)$ of them had normal cognitive function (MoCA 226). Mild cognitive impairment (MoCA 18-26) was found in 65.9\% (29) patients, while moderate cognitive disorder (MoCA 10-17) was detected in 6 (21.6\%) patients. Major cognitive disorder wasn't detected in examined population. Statistically significant correlation was not established between laboratory parameters and overall MoCA score. Statistically significant correlation, however, was established between MoCA item that evaluates space and time orientation and intermediate secondary hyperparathyroidism and space and time orientation and severe secondary hyperparathyroidism. Hemodynamic instability during hemodialysis and silent ischemia of the brain are increasing risk of appearance of cognitive disorders in maintenance hemodialysis patients.
\end{abstract}

Keywords: hemodialysis, cognition, MoCA, secondary hyperparathyroidism

\section{INTRODUCTION}

Cognitive disorders represent a wide variety of disorders; not solely memory disorders. Those are acquired disorders, going from mild cognitive impairment that is barely noticeable and doesn't impact every day activities; to dementia that is not compatible with independent life. Common characteristic for these disorders is clinically significant memory loss. Prevalence of dementia grows with years, from $5-7 \%$ until 65 years of life, to over $50 \%$ in older

\section{SAŽETAK}

Prevalenca kognitivnih premećaja je visoka kod pacijenata koji su na redovnoj hemodijalizi. Od ukupnog broja ispitivanih bolesnika, normalnu funkciju kognicije (MoSA $\geq 26)$ je imalo svega 5 bolesnika (12,5\%). Blagi poremećaj kognicije (MoSA18-26) ima 29 bolesnika (65,9\%), dok je 6 bolesnika $(21,6 \%)$ imalo umereno težak poremećaj kognitivne funkcije (MoSa skor 10-17). Težak kognitivni poremećaj nije otkriven ni kod jednog ispitivanog bolesnika. Ne postoji statistički značajna korelacija između ukupnog MoSA skora i ispitivanih laboratorijskih parametara. Statistički značajna korelacija postoji izmedu dela MoSA skora koji ispituje funkciju orijentacije u prostoru i vremenu i umerenog i teškog sekundarnog hiperparatireoidizma. Hemodinamska nestabilnost u toku hemodijalize i nemi infarkti mozga povećavaju rizik od nastanka poremećaja funkcije kognicije u populaciji bolesnika koji se leče redovnom hemodijalizom.

Ključne reči: hemodijaliza, kognicija, MoSA skor, sekundarni hiperparatireoidizam 
to $20 \%$, and major cognitive disorders prevalence is about $10 \%(6,7)$. Presence of mild cognitive disorder is relative contraindication for initiation of hemodialysis treatment. This comes from the fact that patient has to understand the hemodialysis process itself; and he or she must be able to cooperate with the staff (8). Cognitive disorders diminish quality of life and life expectancy of maintenance hemodialysis patients. In general population, in elder than 75 and with diagnosed Alzheimer disease, life expectancy is about 7.5 years; while life expectancy in maintenance hemodialysis with Alzheimer's is significantly smaller - only 3.3 years $(9,10,11)$. This study had multiple goals: aside of determining of prevalence and severity of established cognitive disorder, we wanted to examine whether gender, maintenance hemodialysis duration, anemia, number of intradialytic hypotension and severity of secondary hyperparathyroidism have impact and in what level on cognitive function.

\section{METODOLOGY}

The research was conducted in Clinic for Urology, Nephrology and Dialysis; in Center for Nephrology and Dialysis of Clinical center "Kragujevac", with design of crosssectional, analytic study. Before onset of the research, all necessary permissions were acquired from local Ethic Comity. Total of 40 maintenance hemodialysis patients that are treated in the Center participated voluntary. Inclusion criteria were: age of 18 years and older, maintenance hemodialysis treatment longer than 3 months, and patients without previous diagnosis of MCI or dementia. Exclusion criterion was any diagnosed cognitive disorder.

\section{Montreal cognitive assessment (MoCA)}

Montreal cognitive assessment (MoCA) is one of the cognition assessment tools, and its revised version has been recently validated for maintenance hemodialysis patients (12). In this population, most common cognitive disorders are in executive functions, lower speed of information processing, lower speech fluency, as well as short term memory of verbal and non-verbal data $(13,14)$. Total score counts 30 points, and it can be obtained by simple addition of max value which can be found next to every item. Lower limit for normal cognition is 26 , and every value lower than this one expresses severity of cognitive disorder. Patients with MCI get between 18-26 points; patients with $10-17$ point are the ones with medium severity cognitive disorder; and those with less than 10 points have major cognitive disorder. In patients with less than 12 years of education, we add 1 point on the observed score (15).

\section{Diagnostic criteria}

Main criterion for diagnosis of dementia was memory disorder (criterion A1) and any of these: aphasia (A2a), apraxia (A2b), agnosia (A2c), executive function disorders (criterion A2d). All represented disorders must be more severe than previously registered cognitive state and cannot be explained by any other psychiatric disease. Along with these symptoms, space and time disorientation, alopersonal and autopersonal disorientation, hallucinations, delusions, disinhibited behavior, cursing, mood and sleep disorders could be presented. Cognitive disorder cannot be diagnosed if listed symptoms represent exclusively during delirium.

\section{Variables}

The primary variable was value of total score of Montreal cognitive assessment (MoCA). Independent variable were: gender, maintenance hemodialysis duration of treatment (from 3 months to 5 years, 5-10 years, and over 10 years) and laboratory parameters: anemia (hemoglobin $(\mathrm{Hb})$ level $<110 \mathrm{~g} / \mathrm{l}$ ), nutritive status (total serum protein levels and albumins), inflammation markers - CRP (Creactive protein), quality of dialysis index (Kt/V), impact of secondary hyperparathyroidism (mild - PTH up to 500 ng/l; intermediate - PTH 500-800 ng/l and severe - PTH over $800 \mathrm{ng} / \mathrm{l}$ ), intradialytic hypotension (every decrease of systolic blood pressure for $20 \mathrm{mmHg}$ and more regarded to systolic pressure at the beginning of hemodialysis) had significant impact on cognition.

\section{Statistics}

Data was analyzed in SPSS version 21.0. Laboratory parameters were calculated as median of three measurements for last three months before onset of data gathering. Data were analyzed with descriptive statistics, normality tests; and according to data distribution pattern, we conducted parametric or non-parametric tests. For correlation determination we used Pearson's correlation coefficient, which significance was determined as significant if $\mathrm{p}$ value was less than $0.05(\mathrm{p}<0.05)$. Multivariable analysis was preformed to determine which of the risk factors can be used as predictor of cognitive decline.

\section{RESULTS}

Our study included 40 maintenance hemodialysis patients, $67.5 \%$ were men and $32.5 \%$ women, with the average age 59.6 \pm 9.2 years. Demographic characteristics are presented in Table 1. Besides of listed main reasons of CKD; there is one patient with endemic nephropathy, one with chronic pyelonephritis, one with rectal carcinoma, and two patients with obstructive nephropathy. Average total MoCA score was $21.75 \pm 3.5$ points. There were no statistically significant differences between genders. MCI (MoCA 18-26) had 29 patients (65.9\%); while intermediate severity cogni- 
Table 1. Basic demographic data on the participants

\begin{tabular}{|c|c|c|}
\hline \multirow{2}{*}{\multicolumn{2}{|c|}{ Variables }} & Values \\
\hline & & $\%, \mathrm{Xsr} \pm \mathrm{SD}$ \\
\hline \multicolumn{2}{|l|}{ Gender $(\mathrm{m}, \mathrm{f})$} & $67.5: 32.5 \%$ \\
\hline \multicolumn{2}{|l|}{ Age (yrs.) } & $59.65 \pm 9.15$ \\
\hline \multirow{2}{*}{ Inhabitance } & Urban & $65.0 \%$ \\
\hline & Rural & $35.0 \%$ \\
\hline \multirow{4}{*}{ Years of education } & Male & $12.63 \pm 3.42$ \\
\hline & Female & $10.85 \pm 1.91$ \\
\hline & Urban & $12.27 \pm 3.36$ \\
\hline & Rural & $11.33 \pm 2.50$ \\
\hline \multicolumn{2}{|c|}{ Duration of HD treatment (months) } & $74.00 \pm 77.05$ \\
\hline \multicolumn{3}{|c|}{ Primary kidney disease } \\
\hline \multicolumn{2}{|c|}{ Renal polycystic disease } & $27.5 \%$ \\
\hline \multicolumn{2}{|c|}{ Chronic glomerulonephritis } & $17.5 \%$ \\
\hline \multicolumn{2}{|c|}{ Nephroangiosclerosis } & $37.5 \%$ \\
\hline \multicolumn{2}{|c|}{ Diabetic nephropathy } & $15.0 \%$ \\
\hline \multicolumn{3}{|l|}{ Underlying disease } \\
\hline \multicolumn{2}{|l|}{ Diabetes type 2} & $15.0 \%$ \\
\hline \multicolumn{2}{|c|}{ Myocardial infarction } & $7.5 \%$ \\
\hline \multicolumn{2}{|l|}{ COPD* } & $10.0 \%$ \\
\hline \multicolumn{2}{|l|}{ Hepatitis B } & $7.5 \%$ \\
\hline \multicolumn{2}{|l|}{ Hepatitis C } & $17.5 \%$. \\
\hline \multicolumn{2}{|l|}{ Stroke } & $2.5 \%$ \\
\hline
\end{tabular}

* Chronic obstructive pulmonary disease

tive disorder (ICI) (MoCA 10-17) had 6 patients (21.6\%). We didn't register patients with major cognitive disorder $(\mathrm{MoCA} \leq 10)$. Patients that had lowest MoCA score in our study had least time spent in education and longest time spent on hemodialysis treatment. Patients didn't connect numbers with letters (57.5\%); $37.5 \%$ had drawn clock correctly, $27.5 \%$ made more than 2 mistakes during deduction of numbers, and only $30 \%$ heard letter A in line. Average count of letter S was 6-8. Only $35 \%$ of participant finished whole task. $35 \%$ of participants made mistake when asked about similarities between two objects. There were no statistically significant differences in laboratory parameters between participants with MCI and ICI (Table 2). There were no statistically significant correlation between laboratory parameters and total MoCA score. Difference in total MoCA score in patients with normal and elevated CRP levels is 1.6 points $(22.70: 21.04)$. Total MoCA score doesn't correlate with total PTH levels, while significant correlation is found in those with intermediate SHPTH (Pearson's correlation -0.993, p <0.001) and severe SHPTH (Pearson's correlation -0.887, $\mathrm{p}<0.005)$ and part of MoCA that assesses space and time orientation. Multivariable analysis showed that only level of ionized iron in blood can be used as predictive factor for cognitive decline $(0.707$; $\mathrm{p}=0.016)$ with high sensitivity (0.97) and medium specificity (0.60).

\section{DISCUSSION}

Participants in this study were predominantly male, of average age of 60 years. Their address was mainly located in town, and they spent around 12 years in education. They have spent $74.0 \pm 77.0$ months on maintenance hemodialysis treatment. Normal cognitive function (MoCA $\geq 26$ ), according to MoCA, had only $12.5 \%$ (5) patients. It is well known fact that maintenance hemodialysis patients have cognitive disorders, and it is commonly under recognized. In different studies, percentage of these disorders goes from $30-87 \%$; and only $3 \%$ is recognized (16). This pathology is common in CKD in all stages (17). Around $65 \%$ of MCI patients later get diagnosed with dementia, and in about $24 \%$ of them dies 11 years after getting diagnosed with dementia (18). Clock drawing test can be very informative when talked about differentiation of dementia (19). Some groups of questions can clearly distinct healthy persons from ones with MCI (20). Our findings correlate with other similar studies (21). Level of CRP in our study did not correlate significantly with global cognitive function unlike previous findings (22-25). Our study showed that elevated PTH levels and severity of secondary hyperparathyroidism statistically significantly correlates with space and time orientation disorders. Influence of elevated PTH levels in primary

Table 2. Influence of risk factors on degree of cognitive disorder

\begin{tabular}{|c|c|c|c|}
\hline Variable & $\begin{array}{c}\mathrm{MCI} \\
\mathrm{Xsr}+\mathrm{SD}\end{array}$ & $\begin{array}{c}\mathrm{ICI} \\
\mathrm{Xsr}+\mathrm{SD}\end{array}$ & P value \\
\hline $\begin{array}{l}\text { Erythrocyte } \\
\text { count }\end{array}$ & $3.37 \pm 0.50$ & $3.26 \pm 0.36$ & $>0.05$ \\
\hline $\begin{array}{l}\text { Hemglobin } \\
(\mathrm{g} / \mathrm{l})\end{array}$ & $102.40 \pm 10.25$ & $94.70 \pm 8.21$ & $>0.05$ \\
\hline Hematocrit & $0.319 \pm 0.33$ & $0.299 \pm 0.24$ & $>0.05$ \\
\hline Iron & $10.83 \pm 3.26$ & $9.07 \pm 2.82$ & $>0.05$ \\
\hline Ferritine & $781.14 \pm 317.05$ & $788.06 \pm 316.77$ & $>0.05$ \\
\hline TSAT & $23.34 \pm 8.76$ & $29.25 \pm 10.80$ & $>0.05$ \\
\hline CRP & $11.8 \pm 15.86$ & $11.06 \pm 8.77$ & $>0.05$ \\
\hline Blood glucose & $6.09 \pm 4.45$ & $5.81 \pm 1.81$ & $>0.05$ \\
\hline Creatinine & $850.08 \pm 191.05$ & $850.84 \pm 181.97$ & $>0.05$ \\
\hline Uric acid & $366.74 \pm 70.3$ & $354.25 \pm 98.73$ & $>0.05$ \\
\hline $\mathrm{Kt} / \mathrm{V}$ & $0.99 \pm 0.22$ & $1.21 \pm 0.42$ & $>0.05$ \\
\hline Total proteins & $62.33 \pm 5.40$ & $57.92 \pm 11.80$ & $>0.05$ \\
\hline Albumin & $35.84 \pm 4.21$ & $37.63 \pm 3.03$ & $>0.05$ \\
\hline $\mathrm{Ca}$ & $2.16 \pm 0.20$ & $2.0 \pm 0.24$ & $>0.05$ \\
\hline PO4 & $1.66 \pm 0.46$ & $1.91 \pm 0.40$ & $>0.05$ \\
\hline CaxP & $3.45 \pm 1.19$ & $3.16 \pm 1.48$ & $>0.05$ \\
\hline iPTH & $312.54 \pm 353.19$ & $687.30 \pm 685.72$ & $<0.01$ \\
\hline $\begin{array}{l}\text { Hypotension } \\
\text { number(3 } \\
\text { months) }\end{array}$ & $17.42 \pm 7.94$ & $14.0 \pm 11.20$ & $>0.05$ \\
\hline $\begin{array}{l}\text { Average } \\
\text { systolic } \\
\text { pressure }\end{array}$ & $131.41 \pm 15.58$ & $121.70 \pm 9.6$ & $>0.05$ \\
\hline
\end{tabular}


hyperparathyroidism is documented, when total cognitive function elevation was detected after parathyroidectomy $(26,27)$. There was one case of dementia as presentation of primary hyperparathyroidism (28). In SHPTH, in maintenance hemodialysis population, growth of global cognitive function was noted after parathyroidectomy (29). In general population, elevated PTH levels can predict decrease of global cognitive function during 5 years, independent from renal function (30).

Cause of these disorders is still unrecognized. Anatomically, in hemodialysis patients' population more frequent is cerebral atrophy, hippocampal atrophy and silent ischemia (31). Taken that predominantly executive and orientation function are affected; it is indicated that risk factors are the same as in vascular diseases (4). Hemodynamic instability during hemodialysis, frequent asymptomatic intradialytic hypotension, especially in elder patients and those with longer treatment period have important role in functionality of sensitive anatomic structures (32-34).

\section{Strengths and limitations}

The results of our study should be considered into its limitations such as not enough examined risk factors, and the design of study that doesn't allow patient follow-up. On the other side, the study strengths were use of MoCA score, which is clinically significant, as well as it is highly sensitive for MCI detection. Further study should be longitudinal, have more details in anamnesis, and have more detailed cognition testing.

\section{CONCLUSION}

Cognitive disorders are very common in maintenance hemodialysis patient. In spite of that; they are highly under recognized. Being as they are, they represent occult risk factor; they make doctor - patient cooperation difficult, they aggravate education process and adaptation of patient to treatment itself, so it makes them increased mortality factor in this patient population.

\section{REFERENCES}

1. Slavica Đukić Dejanović, Vladimir Janjić, Goran Mihajlović, Danijela Đoković, Dragana Ignjatović Ristić, Dragan Ravanić i saradnici, Psihijatrija, Medicinski fakultet Univerziteta u Kragujevcu, 2011; str. 271-282.

2. Grams ME, Chow EK, Segev DL, Coresh J. Lifetime incidence of CKD stages 3-5 in the United States. Am J Kidney Dis. 2013; 62(2):245-52.

3. Bowling CB, Muntner P, Sawyer P, Sanders PW, Kutner $\mathrm{N}$, et al. Community mobility among older adults with reduced kidney function: a study of life-space. Am J Kidney Dis. 2014; 63(3):429-36.
4. Sarnak MJ, Tighiouart H, Scott TM, Lou KV, Sorensen EP, Giang LM, et al. Frequency of and risk factors for poor cognitive performance in hemodialysis patients. Neurology. 2013; 80(50):471-80.

5. Pereira AA, Weiner DE, Scott T, Sarnak MJ. Cognitive function in dialysis patients. Am J Kidney Dis. 2005; 45(3):448-62.

6. Sehgal AR, Grey SF, DeOreo PB, Whitehouse PJ. Prevalence, recognition, and implications of mental impairment among hemodialysis patients. Am J Kidney Dis. 1997; 30(1):41-9.

7. Kutlay S, Nergizoglu G, Duman N, Atli T, Keven K, Ertürk S, et al. Recognition of neurocognitive dysfunction in chronic hemodialysis patients. Ren Fail. 2001; 23(6):781-7.

8. Moss AH. Shared decision-making in dialysis: the new RPA/ASN guideline on appropriate initiation and withdrawal of treatment. Am J Kidney Dis. 2001; 37(5):1081-91.

9. Griva K, Stygall J, Hankins M, Davenport A, Harrison M, Newman SP. Cognitive impairment and 7-year mortality in dialysis patients. Am J Kidney Dis. 2010; 56(4):693-703.

10. Larson EB, Shadlen MF, Wang L, McCormick WC, Bowen JD, Teri L, et al. Survival after initial diagnosis of Alzheimer disease. Ann Intern Med. 2004; 6:140(7):501-9.

11. Tschanz JT, Corcoran C, Skoog I, Khachaturian AS, Herrick J, Hayden KM, et al. Cache County Study Group. Dementia: the leading predictor of death in a defined elderly population:the Cache County Study. Neurology. 2004; 62(7):1156-62.

12. Nasreddine ZS, Phillips NA, Bédirian V, Charbonneau S, Whitehead V, Collin I,Et al. The Montreal Cognitive Assessment, MoCA: a brief screening tool for mild cognitive impairment. J Am Geriatr Soc. 2005; 53(4):695-9.

13. Tiffin-Richards FE, Costa AS, Holschbach B, Frank RD, Vassiliadou A, Krüger T et al. The Montreal Cognitive Assessment (MoCA) - a sensitive screening instrument for detecting cognitive impairment in chronic hemodialysis patients. PLoS One. 2014;9(10):e106700

14. Yaffe K, Ackerson L, Kurella Tamura M, Le Blanc P, Kusek JW, Sehgal AR, et al.;Chronic Renal Insufficiency Cohort Investigators. Chronic kidney disease and cognitive function in older adults: findings from the chronic renal insufficiency cohort cognitive study. J Am Geriatr Soc. 2010; 58(2):338-45.

15. Montreal Cognitive Assessment test, MoCA test as published online: http://www.mocatest.org/faq/

16. Murray AM. Cognitive impairment in the aging dialysis and chronic kidney disease populations: an occult burden. Adv Chronic Kidney Dis. 2008; 15(2):123-32.

17. Paraizo MA, Almeida AL, Pires LA, Abrita RS, Crivellari $\mathrm{MH}$, Pereira BD, et al. Montreal Cognitive Assessment (MoCA) screening mild cognitive impairment in patients with chronic kidney disease (CKD) predialysis.J Bras Nefrol. 2016; 38(1):31-41. 
18. Yaffe K, Petersen RC, Lindquist K, Kramer J, Miller B. Subtype of mild cognitive impairment and progression to dementia and death. Dement Geriatr Cogn Disord. 2006; 22(4):312-9.

19. Price CC, Cunningham H, Coronado N, Freedland A, Cosentino S, Penney DL, et al. Clock drawing in the Montreal Cognitive Assessment: recommendations for dementia assessment. Dement Geriatr Cogn Disord. 2011;31(3):179-87.

20. Cecato JF, Martinelli JE, Izbicki R, Yassuda MS, Aprahamian I. A subtest analysis of the Montreal cognitive assessment (MoCA): which subtests can best discriminate between healthy controls, mild cognitive impairment and Alzheimer's disease? Int Psychogeriatr. 2016; 28(5):825-32.

21. Pliskin NH, Yurk HM, Ho LT, Umans JG. Neurocognitive function in chronic hemodialysis patients. Kidney Int. 1996; 49(5):1435-40.

22. Engelhart MJ, Geerlings MI, Meijer J, Kiliaan A, Ruitenberg A, van Swieten JC, et al. Inflammatory proteins in plasma and the risk of dementia: the rotterdam study. Arch Neurol. 2004; 61(5):668-72.

23. Bredesen DE. Metabolic profiling distinguishes three subtypes of Alzheimer's disease. Aging (Albany NY). 2015; 7(8):595-600.

24. Teunissen CE, van Boxtel MP, Bosma H, Bosmans E, Delanghe J, De Bruijn C, et al. Inflammation markers in relation to cognition in a healthy aging population. J Neuroimmunol. 2003; 134(1-2):142-50.

25. Watanabe Y, Kitamura K, Nakamura K, Sanpei K, Wakasugi M, Yokoseki A, et al. Elevated C-Reactive Protein Is Associated with Cognitive Decline in Outpatients of a General Hospital: The Project in Sado for Total Health (PROST). Dement Geriatr Cogn Dis Extra. 2016; 19;6(1):10-9.
26. Roman SA, Sosa JA, Mayes L, Desmond E, Boudourakis L, Lin R, et al. Parathyroidectomy improves neurocognitive deficits in patients with primary hyperparathyroidism. Surgery. 2005; 138(6):1121-8.

27. Walker MD, McMahon DJ, Inabnet WB, Lazar RM, Brown I, Vardy S, et al. Neuropsychological features in primary hyperparathyroidism: a prospective study. J Clin Endocrinol Metab. 2009; 94(6):1951-8.

28. Papageorgiou SG, Christou Y, Kontaxis T, Bonakis A, Anagnostouli M, Potagas C, et al. Dementia as presenting symptom of primary hyperparathyroidism: favourable outcome after surgery. Clin Neurol Neurosurg. 2008; 110(10):1038-40.

29. Chou FF, Chen JB, Hsieh KC, Liou CW. Cognitive changes after parathyroidectomy in patients with secondary hyperparathyroidism. Surgery. 2008; 143(4):526-32.

30. Björkman MP, Sorva AJ, Tilvis RS. Does elevated parathyroid hormone concentration predict cognitive decline in older people? Aging Clin Exp Res. 2010; 22(2):164-9.

31. Drew DA, Bhadelia R, Tighiouart H, Novak V, Scott TM, Lou KV, et al. Anatomic brain disease in hemodialysis patients: a cross-sectional study. Am J Kidney Dis. 2013; 61(2):271-8

32. Prohovnik I, Post J, Uribarri J, Lee H, Sandu O, Langhoff E. Cerebrovascular effects of hemodialysis in chronic kidney disease. J Cereb Blood Flow Metab. 2007; 27(11):1861-9.

33. Narumoto J, Matsushima N, Oka S, Shimizu H, Kooguchi Y, Kitabayashi Y, et al. Neurobehavioral changes associated with bilateral caudate nucleus infarctions. Psychiatry Clin Neurosci. 2005; 59(1):109-10.

34. Murray AM. Cognitive impairment in the aging dialysis and chronic kidney disease populations: an occult burden. Adv Chronic Kidney Dis. 2008; 15(2):123-32. 